\title{
Pitágoras, Alejandro, Rafael y la Serratia marcescens
}

\author{
WALTER LEDERMANN D.
}

\section{Pithagoras, Alexander, Raphael and the Serratia marcescens}

Es difícil que otra bacteria pueda exhibir una historia tan plena de accidentes dramáticos ni tan ligada a la tontería humana como Serratia marcescens. Descrita (con gruesos errores) y denominada así por Bartolomeo Bizio en 1823, en la época pre-pasteuriana, el nombre ha persistido a través del tiempo, hasta convertirse en el más antiguo de los binomiales actualmente aceptados por los comités internacionales de taxonomía bacteriana. Su singularidad, causa de toda su romántica historia, descansa en la capacidad de algunas cepas para producir un pigmento rojo, tan sangriento y sorprendente, que ha merecido el nombre de prodigiosina. Este pigmento, desarrollado en alimentos farináceos, en los cuales la bacteria crece con facilidad, ha sido confundido con sangre y, como la estupidez humana es infinita, ha terminado casi siempre por generar torrentes de la verdadera.

Ferdinand Cohn, uno de los padres de la microbiología, ha querido remontar la historia se Serratia marcescens hasta el siglo IV a.C., basándose en algunas creencias de Pitágoras expuestas en la obra satírica Vitarium auctio, del dramaturgo griego Luciano de Samosata (170 d.C.). Bien pudo Cohn ir más atrás en el tiempo, pues Pitágoras vivió en el siglo VI a.C., ya que la primera noticia cierta de su vida dice que en el 530 a.C. abandonó su isla natal de Samos, escapando a la tiranía de Polícrates, para establecerse en Crotón, al sur de Italia. Conocido por la posteridad como geómetra y matemático, en vida el propio Pitágoras se consideró filósofo y propició una forma de vida que lo ubica entre los primeros ecologistas, oponiéndose a matar animales y a comer su carne. De acuerdo a los escritos del emperador Empédocles, quien parece haber compartido los ideales pitagóricos, el derramamiento de sangre constituía el pecado original: quien lo cometiere, vería su alma exiliada del cuerpo y condenada a vagar en un mundo de formas mortales, en sucesivas reencarnaciones, hasta que a su vez alguien le diera muerte sangrienta, así liberándola.

Lo curioso -y lo que termina por relacionar al filósofo con la bacteria- es que el maestro prohibía a sus discípulos y seguidores no sólo comer carne, estándoles también vedado comer porotos. Pitágoras no dejó escritos que explicaran esta singular prohibición y Cohn, que rastreó las menciones de ésta desde Diógenes (siglo IV a.C.) hasta Porfirio (siglo V d.C.), no encontró interpretación alguna que fuese válida.
En la mencionada Vitarium auctio, Luciano pone en boca de un pitagórico la siguiente explicación: "Hierve uno (un poroto) y éxponlo a la luz de la luna por un adecuado número de noches y tendrás sangre". Asume Cohn que, en alguna circunstancia, vio Pitágoras la roja putrefacción de un poroto y creyó que sangraba, incluyéndolo ipso facto entre los alimentos prohibidos. El filósofo obró así en forma precipitada y lo mismo pudo haber hecho el bacteriólogo al imputar sin más el enrojecimiento a Serratia. En nuestra modesta búsqueda encontramos, en una antigua edición de Bergey's otra posibilidad: "Pseudomonas beijerinckii, Hof 1935... insoluble purple pigment". Se menciona como fuente de aislamiento "seis cepas aisladas de porotos preservados con sal", señalándose, al definir su hábitat normal, que "causa decoloración púrpura de porotos salados". Cocidos, dice el personaje de Luciano. Es lógico pensar que Pitágoras vio más de una vez enrojecer a los porotos $\mathrm{y}$, si fue un hecho frecuente, es también lógico pensar que mayores fueron las probabilidades para Pseudomonas beijerinckii, patógeno natural del poroto, que para Serratia marcescens, una oportunista más propia de los alimentos farináceos, como ya veremos. Ahora bien, la sinonimia existente entre porotos y habichuelas, ha inducido a confusión y en algunos textos se sostiene que la prohibición de Pitágoras se refería a las habas y no a los porotos. Así ocurre en la Botánica Oculta del catalán Juan Perucho, quien - con su habitual desenfado - se burla del filósofo y lo hace perecer a manos de unos asaltantes por evitar, en su huida, pisar un campo de maléficas habas: "estos enigmáticos seres con sangre".

No debe sorprender que se ligue con tanta ligereza a este gran matemático con la Serratia, pues a lo largo de siglos su figura ha estado relacionada a una serie de prodigios: dícese que tenía un muslo de oro legítimo, que dio conferencias simultáneas en dos distintos lugares geográficos, que era una encarnación del dios Apolo y, para los primeros cristianos, un intermediario entre Moisés y Platón. Nosotros preferimos recordarlo por su teorema, la música de las esferas y la Serratia marcescens, olvidándonos de la magia.

Es difícil separar, en las antiguas descripciones, la verdad de la fantasía, y casi imposible establecer la hipotética participación de Serratia marcescens y de su pigmento en la gran mayoría de los prodigios registrados a través de los tiempos. De los más 
convincentes, el más antiguo se refiere al sitio de Tiro por Alejandro Magno, en el año 332 a.C., magistralmente relatado por el historiador Quinto Curcio Rufo en su Historia de Alejandro. Tiro, una isla separada del continente por "un brazo de mar de cuatro estadios" (unos ochocientos metros), convenientemente fortificada y con muros en acantilado, era inexpugnable. En esa confianza, los tirios negaron, con irónica cortesía, la entrada al conquistador, quien pretendía hacer un sacrificio en el templo de Hércules. No pudiendo dominar su ira, Alejandro les dijo: "...porque habitáis en una isla, menospreciáis este ejército de tierra, pero en breve os demostraré que vivís en un continente".

Esta oscura amenaza hizo sonreír a los isleños. Alejandro había concebido - y no demoró en ponerla en práctica - la fabulosa idea de construir un muelle hasta la isla, titánica obra de ingeniería militar en que consumió siete meses y numerosas vidas, segadas por los continuos ataques "comando" de las veloces naves tirias. En una ocasión, un brulote lanzado desde la isla quemó el muelle, destruyéndolo; los macedonios insistieron, improvisando otro con sus navíos, atados de dos en dos por la proa, pero el viento los dispersó y fue necesario emprender la construcción de uno nuevo. Alejandro estaba trémulo de rabia por este imprevisto retraso frente a una ciudad insignificante; había enviado heraldos de paz y éstos asesinados por los tirios; el tiempo transcurría y sólo su orgullo le impedía levantar el sitio y reconocer su fracaso. Numerosos augurios alentaban a uno y otro bando, pero dos presagios de sangre vinieron en ayuda del hijo de Filipo: en Tiro, bajo las llamas de una fragua, se hicieron visibles riachuelos de sangre, que dieron tanta confianza a los isleños como para descuidar sus defensas, en tanto que en el campamento macedonio...

¡Apareció la Serratia! Dice Curcio Rufo que “ unos soldados, en el momento de cortar unas rebanadas de pan, vieron brotar unas gotas de sangre; el rey se asustó y Aristandro, el más entendido de los adivinos, declaró, que si la sangre se hubiera vertido por la parte de afuera hubiera sido un mal presagio, pero, por el contrario, puesto que fluía de la parte de adentro, anunciaba la pérdida de la ciudad".

Cuánto influyó en el ánimo y en el triunfo final este prodigio, nadie puede decirlo, pero la ciudad cayó. Después de una afortunada victoria naval, en que destruyó a la flota tiria, Alejandro " con gran valor subió a la torre más alta, aunque con más grande peligro ya que, vistiendo todas las insignias de la realeza y por el fulgor de sus armas, era entre todos el mejor blanco de los disparos. Entonces hizo cosas dignas de contemplarse..." (Es decir, una matanza).

Si la Serratia efectivamente contaminó el pan y si este hecho, ocurrido al parecer al inicio del sitio, fue decisivo en el resultado de la contienda, la prodigiosina hizo correr mucha sangre. $\mathrm{Y}$, ciertamente, fluyó entonces de adentro: "Alejandro ordena que a todos les sea aplicada la pena de muerte y que se prenda fuego a todas las casas. Publicadas estas órdenes por los pregoneros, nadie que estu- viera armado se resignó con pedir ayuda a los dioses". Seis mil tirios fueron inmolados dentro de las murallas y dos mil crucificados a guisa de escarmiento, calculándose en treinta mil los que fueron vendidos como esclavos. Tiro quedó en ruinas. El episodio aparece confirmado por otro historiador, el griego Diodoros Siculus, dos siglos después de Rufo: "los pedazos de pan partido tenían apariencia sangrienta".

A mediados del siglo diecinueve, Christian Ehrenberg revisó todas las posibles participaciones de esta bacteria (que pretendió llamar Monas prodigiosa en 1849, desconociendo a Bizio) en milagros de panes y hostias sangrantes. Remontándose a leyendas hebreas y mahometanas, llegó a citar más de cincuenta episodios milagrosos, algunos de cuales pudieron realmente corresponder a causa microbiana. De ellos mencionaremos el de Bolsena, pues fue decisivo en la celebración de la fiesta de Corpus Christi.

Aunque la celebración del sacramento de la Eucaristía estaba aprobada por el Concilio de Roma en 1709, en el 1264 aun existían dudas al respecto. El Papa Urbano IV vacilaba en hacerla extensiva a toda la Iglesia, cuando un milagro vino a decidirlo. El Papa y su corte pasaban el verano en Civitavechia, en la zona costera del norte de Roma, y había autorizado la celebración de Corpus en una iglesia que estaba a pocas millas, en el lago Bolsena. Durante la ceremonia y al momento de bendecir los elementos de la comunión, el sacerdote, quien pasaba por una crisis de fe, vio como desde la hostia goteaba sangre, que manchaba su hábito. Atemorizado, quiso ocultar la evidencia plegando el hábito, pero más sangre apareció en la hostia. El milagro hizo que Urbano emitiese una bula papal -Transiturus de hoc mundo- ese mismo año, decretando Corpus Christi como una fiesta para toda la Iglesia Católica y generadora de muchas indulgencias. El hábito ensangrentado se exhibió hasta tiempos muy recientes en Civitavechia.

En 1508, el célebre Rafael aceptó el patrocinio del Papa Julio II y comenzó a decorar los aposentos del Vaticano. Su primer trabajo fue la oficina del Papa, la llamada stanza della signatura y de ahí pasó a la "cámara de Eliodoro", donde pintó el fresco conocido como "El milagro o La misa de Bolsena", donde se ve la hostia goteando sangre. Ehrenberg pretendió negar el milagro y atribuir el suceso a la prodigiosina : como este pigmento permanece en la colonia y no chorrea, y como no se encontró otra explicación física, nos declaramos de acuerdo con Urbano y Rafael y lo consideramos milagroso.

Distinto es el caso ocurrido en la iglesia de Wilsnack, Alemania, en el año 1383, que tiene un gran interés bacteriológico. El sacerdote dejó sobre el altar tres hostias consagradas, destinadas a los enfermos; luego de ocho días y tras una lluviosa noche, las hostias, que estaban secas en medio de un altar húmedo, comenzaron a ensangrentarse, fenómeno que fue progresando en los días sucesivos. Para tranquilizar a la horrorizada población, el obispo de Havelberg vino a decir misa. Dudoso de las 
hostias rojas, trajo una de su ciudad, poniéndola sobre tela del altar "entre las otras tres". Aunque consagrada, también ésta terminó por enrojecer. La humedad, el tiempo transcurrido, el progresivo aumento de la pigmentación, la transmisión a la nueva hostia, todo parece avalar la presencia de Serratia marcescens. Pero el milagro quedó establecido, los peregrinos llegaron por millares y se sucedieron las curaciones milagrosas. Nada dura: los luteranos llegaron al poder en 1535, destruyeron el receptáculo que contenía los restos de las hostias milagrosas y quemaron su contenido. Al cabo de algunas décadas todos los peregrinos habían desaparecido y Wilsnack estaba despoblada.

Extraordinaria bacteria. Más de quinientos años antes de su descubrimiento, ya se había relacionado con Pitágoras, Alejandro y Rafael. También se relacionó, indirectamente, con Shakespeare en una oportunidad. Pero lo contaremos en otra ocasión, cuan- do queramos relatar toda la historia de este microbio, que recién empieza en 1819, con Bartolomeo Bizio y la curiosa historia de "la polenta sangrienta".

\section{Bibliografía}

1.- Robinson J. Pythagoras. En : Halsey W.D. Collier's Encyclopedia. Crower Collier \& Mc Millan, Phi 1967; 19: $547-8$

2.- Gaughran E. From superstition to science : the history of a bacterium. Trans N Y Acad Sci 1969; 31: 3-24.

3.- Perucho J. Botánica oculta o el falso Paracelso. Plaza Janés, Barcelona 1986; p 15.

4.- Curcio Rufo Q. Historia de Alejandro Magno. Editorial Iberia, Barcelona 1960; pp 32-42.

5.- Yu V. Serratia marcescens. Historical perspective and clinical review. N Engl J Med 1979; 300: 887-93.

6.- Merlino C. Bartolomeo Bizio's letter to the most eminent priest, Angelo Bellani, sopra il fenomeno della polenta porporina. J Bacteriol 1924; 9: 527-43. 